\title{
Amino acid residues involved in agonist binding and its linking to channel gating, proximal to transmembrane domain of $5-\mathrm{HT}_{3 \mathrm{~A}}$ receptor for halothane modulation
}

\author{
Department of Anesthesiology and Pain Medicine, Kyung Hee University College of Medicine, \\ *Department of Anesthesiology and Pain Medicine, Research Institute of Anesthesia and Pain, Yonsei University College of Medicine, Seoul, Korea
}

\author{
Mi Kyeong Kim, Kyeong Tae Min*, and Bon Nyeo Koo*
}

\begin{abstract}
Background: The 5-hydroxytryptamine type $3\left(5-\mathrm{HT}_{3}\right)$ receptor is a member of the Cys-loop superfamily of ligand-gated ion channels (LGICs) and modulated by pharmacologic relevant concentrations of volatile anesthetics or n-alcohols like most receptors of LGICs. The goal of this study was to reveal whether the site-directed single mutations of E-106, F-107 and R-222 in 5-HT 3 receptor may affect the anesthetic modulation of halothane known as positive modulator.

Methods: The wild-type and mutant receptors, E106D, F107Y, R222F, R222V, were expressed in Xenopus Laevis oocytes and receptor function was assessed using two electrode voltage clamp techniques.

Results: E106D, F107Y, R222F, R222V mutant 5- $\mathrm{HT}_{3 \mathrm{~A}}$ receptors were functionally expressed. F107Y mutant 5-HT $3 \mathrm{~A}$ receptors displayed decreased sensitivity to 5-HT compared to the wild type 5- $\mathrm{HT}_{3 \mathrm{~A}}$ receptor $(\mathrm{P}<0.05)$. Halothane showed positive modulation in both wild and $\mathrm{F} 107 \mathrm{Y}$ mutant 5- $\mathrm{HT}_{3 \mathrm{~A}}$ receptors but $\mathrm{F} 107 \mathrm{Y}$ mutant 5- $\mathrm{HT}_{3}$ receptor showed greater enhancing modulation comparing to wild-type receptor. Meanwhile, R222F and R222V mutant 5- $\mathrm{HT}_{3}$ receptor lost positive modulation with 1 and 2 MAC of halothane. Most interestingly, positive modulation by halothane was converted into negative modulation in E106D mutant 5- $\mathrm{HT}_{3 \mathrm{~A}}$ receptor.

Conclusions: The present study implicate the amino acid residues known for agonist binding and linking agonist binding to channel gating might also have important role for anesthetic modulation in 5- $\mathrm{HT}_{3 \mathrm{~A}}$ receptor. (Korean J Anesthesiol 2009; 56: 66 73)
\end{abstract}

Key Words: Electrophysiology, 5- $\mathrm{HT}_{3 \mathrm{~A}}$ receptor, 5-HT, Halothane, Site-directed single mutation, Xenopus Laevis oocytes.

\section{INTRODUCTION}

The 5-hydroxytryptamine type $3\left(5-\mathrm{HT}_{3}\right)$ receptor is a member of the Cys-loop superfamily of ligand-gated ion channels (LGICs) that includes the nicotinic acetylcholine, glycine, and [gamma]-amino butyric acid type A (GABA $)$ receptors. ${ }^{1)}$ Among the five subunits (A-E) cloned to date, 5- $\mathrm{HT}_{3 \mathrm{~A}}$ and $5-\mathrm{HT}_{3 \mathrm{~B}}$ subunits have been demonstrated to have functional significance in the central and peripheral nervous systems. The

Received: December 1, 2008.

Accepted: December 5, 2008.

Corresponding author: Bon Nyeo Koo, M.D., Department of Anesthesiology and Pain Medicine, Yonsei University College of Medicine, Research Institute of Anesthesia and Pain, 134, Sinchon-dong, Seodaemun-gu, Seoul 120-752, Korea. Tel: 82-2-2228-2422, Fax: 82-2-312-7185, E-mail: koobn@yuhs.ac

Copyright (C) Korean Society of Anesthesiologists, 2009
5- $\mathrm{HT}_{3 \mathrm{~B}}$ subunit must be coexpressed with the 5- $\mathrm{HT}_{3 \mathrm{~A}}$ subunit to be functional in peripheral nervous system, whereas the $5-\mathrm{HT}_{3 \mathrm{~A}}$ subunit can form functional channels homomerically and such a homomer is predominantly expressed in central and peripheral nervous systems. ${ }^{2-4)}$

Receptors in superfamily of LGICs are comprised of a pentameric arrangement with each subunit containing a large extracellular N-terminal domain, four transmembrane domains (TM1-TM4), a large intracellular loop between TM3 and TM4, and an extracellular C-terminal domain. ${ }^{5)}$ The structure and function of LGICs is under intense investigation but still ambiguously defined. The ligand binding sites are thought to be located in the extracellular N-terminal domain at subunit-subunit interface, and the channel pore is believed to be formed by TM2. ${ }^{5)}$ Activation of LGICs involves that the binding of neurotransmitter to the closed, resting state receptors triggers a complex conformational change which results in the opening 
the channels. Many electrophysiological studies of volatile anesthetics have focused on their effects on LGICs. Like most receptors of LGICs, $5-\mathrm{HT}_{3}$ receptor is modulated by pharmacologic relevant concentrations of volatile anesthetics or n-alcohols. ${ }^{6,7)}$ Most volatile anesthetics, such as desflurane, isoflurane, halothane, enflurane and methoxyflurane potentiate $5-\mathrm{HT}_{3}$ receptor at their human alveolar concentrations. ${ }^{7-11)}$ However, sevoflurane and two gaseous anesthetics (nitrous oxide, xenon) and intravenous anesthetics, such as pentobarbital and propofol, inhibited the $5-\mathrm{HT}_{3 \mathrm{~A}}$ receptor. ${ }^{11-13)}$ Studies of chimera or single residue mutagenic recombinant receptors of LGICs suggested that the function of LIGS was characterized by the $\mathrm{N}$-terminal domain rather than transmembrane domains and C-terminal domain and channel gating sites are located in TM2. ${ }^{14)}$ The majority of study of anesthetic modulation in LGICs were focused in amino acid residues in TM2 associated with the channel gating. ${ }^{15-19)}$ But for the receptor to be activated, several amino acids in the proximal area of TM1 are also important for agonist recognition (glutamate 106 and phenylalanine 107 in $\mathrm{N}$-terminal area) and possible coupling (arginine 222 in pre TM1 domain) between agonist binding and gating. ${ }^{20-22)}$ In chimeric receptor of $\mathrm{N}$-terminal domain from nACh alpha 7 receptor and the TM and C-terminal domains from $5-\mathrm{HT}_{3}$ receptor, modulation by isoflurane was involved the N-terminal domain of the receptor, which means that the anesthetic modulation in receptor may be also characterized by the $\mathrm{N}$-terminal domain. ${ }^{23)}$ Considering that three amino acids in the proximal to TM1 domain of 5- $\mathrm{HT}_{3}$ receptor are important for agonist binding (glutamate $106^{21)}$ and phenylalanine $107^{20)}$ ) and coupling of agonist binding and channel gating (arginine 222 22 ), the anesthetic modulatory effect might be affected by the mutagenesis of the N-terminal domain of 5- $\mathrm{HT}_{3}$ receptor, especially glutamate 106 and phenylalanine 107 known for agonist binding sites, and the arginine 222 in the pre-TM1 domain known for linking agonist binding to channel gating of $5-\mathrm{HT}_{3}$ receptor.

So this study was intended to reveal whether the mutations of E-106, F-107 and R-222 at the N-terminal domain and pre-TM1 domain may affect the anesthetic modulation of halothane known as positive modulator in $5-\mathrm{HT}_{3}$ receptor expressed in Xenopus Laevis oocytes using two electrode voltage clamp techniques.

\section{MATERIALS AND METHODS}

Site-directed mutagenesis of the $5-\mathrm{HT}_{3 \mathrm{~A}}$ cDNA

A cDNA isolated from the mouse $5-\mathrm{HT}_{3 \mathrm{~A}}$ receptor was generously provided by Dr. Jay Yang (Columbia University, USA). Seven kinds of mutant 5-HT $3 \mathrm{~A}$ receptor were constructed. Glutamate (E) 106 was mutated into aspartate (E106D) or tyrosine (E106Y), phenylalanine $(\mathrm{F}) 107$ into tyrosine (F107Y) or serine (F107S), and arginine (R) 222 into proline (R222P), phenylalanine $(\mathrm{R} 222 \mathrm{~F})$ and valine $(\mathrm{R} 222 \mathrm{~V})$, respectively.

For site-directed mutagenesis, sense and antisense primer oligonucleotides used were as following;

\section{E106D}

Sense primer oligonucleotides:

5'CTGACATTCTCATCAATGACTTTGTGGACGTGGGG3'

Anti sense primer oligonucleotides:

5'CCCCACGTCCACAAAGTCATTGATGAGAATGTCAG3'

E106Y

Sense primer oligonucleotides:

5'TCCCTGACATTCTCATCAATTACTTTGTGGACGTGGGGAAG3'

Anti sense primer oligonucleotides:

5'CTTCCCCACGTCCACAAAGTAATTGATGAGAATGTCAGGGA3'

F107Y

Sense primer oligonucleotides:

5' TGACATTCTCATCAATGAGTACGTGGACGTGGGGAAGTC3'

Anti sense primer oligonucleotides:

5'GACTTCCCCACGTCCACGTACTCATTGATGAGAATGTCA3'

F107S

Sense primer oligonucleotides:

5'CCTGACATTCTCATCAATGAGAGCGTGGACGTGGGGAAGTC3'

Anti sense primer oligonucleotides:

5'GACTTCCCCACGTCCACGCTCTCATTGATGAGAATGTCAGG3'

$\mathrm{R} 222 \mathrm{P}$

Sense primer oligonucleotides:

5'CGTGATCATCCGCCGGCCACCTTTATTCTATGCAGTCAG3' 
Anti sense primer oligonucleotides:

5'CTGACTGCATAGAATAAAGGTGGCCGGCGGATGATCACT3,

$\mathrm{R} 222 \mathrm{~F}$

Sense primer oligonucleotides:

5'ACGTGATCATCCGCCGGTTCCCTTTATTCTATGCAGTCAGC3'

Anti sense primer oligonucleotides:

5 'GCTGACTGCATAGAATAAAGGGAACCGGCGGATGATCACGT3'

R222V

Sense primer oligonucleotides:

5'ACGTGATCATCCGCCGGGTACCTTTATTCTATGCAGTCAGC3'

Anti sense primer oligonucleotides:

5'GCTGACTGCATAGAATAAAGGTACCCGGCGGATGATCACGT3'

Point mutation of the mouse $5-\mathrm{HT}_{3 \mathrm{~A}}$ receptor was accomplished using a Quickchange site-directed mutagenesis kit (Stragene, USA) using the $20-25$ bp oligonucleotide sized primer via Generunner v3.02 (Hastings software Inc., USA). The successful incorporation of mutation was verified by sequencing the clones using an automated DNA sequencer (Genetic Analyzer 3100, USA).

Expression of 5-HT $\mathrm{HA}_{3 \mathrm{~A}}$ receptors into Xenopus laevis oocytes

Wild-type and point mutant mouse $5-\mathrm{HT}_{3 \mathrm{~A}}$ receptor cDNAs were subcloned into a custom oocyte expression vector, pCR-Script $\mathrm{SK}(+)$ and linearized by $\mathrm{Sal}$ I digestion, to prepare template cDNA. cRNA was synthesized in vitro using T3 RNA polymerase (Message Machine, Ambion, USA) following manufacturer's recommended protocol.

All procedures for animal care and use were approved by the Yonsei University committee on Animal Care. Frogs were anesthetized by cold-emersion anesthesia with $0.15 \%$ 3-p-aminobenzoic acid for $30 \mathrm{~min}$. Through a small incision in the frog's abdomen, ovarian lobes were placed in modified Barth's Solution (MBS) ( $\mathrm{NaCl} 88 \mathrm{mM}, \mathrm{KCl} 1 \mathrm{mM}, \mathrm{CaCl}_{2} 0.41 \mathrm{mM}$, $\mathrm{Ca}\left(\mathrm{NO}_{3}\right)_{2} \quad 0.33 \mathrm{mM}, \mathrm{NaHCO}_{3} 2.4 \mathrm{mM}, \mathrm{MgSO}_{4} 0.83 \mathrm{mM}$, Na pyruvate $250 \mathrm{mM}$, HEPES $5 \mathrm{mM}, \mathrm{pH} 7.4$, theophylline 0.5 $\mathrm{mM}$, Penicillin $10 \mathrm{U} / \mathrm{ml}$, streptomycin $10 \mathrm{U} / \mathrm{ml}$, gentamycin 10 $\mathrm{U} / \mathrm{ml})$. Ovarian lobes were manually dissected into clumps of 4 to 10 oocytes and then treated with $1.5 \mathrm{mg} / \mathrm{mL}$ collagenase IA in $\mathrm{Ca}^{2+}$ free frog Ringer's solution $(\mathrm{NaCl} 120 \mathrm{mM}, \mathrm{KCl} 2$
$\mathrm{mM}$, HEPES $5 \mathrm{mM}, \mathrm{pH}$ 7.4) for $30 \mathrm{~min}$ to remove the follicular-cell layer. After the oocytes were rinsed several times, approximately $50 \mathrm{ng}$ of cRNA was injected into stage V-VI oocytes by using a microinjector (Nanojector, Drummond Scientific, USA). Oocytes were incubated in modified MBS $\left(\mathrm{NaCl} 88 \mathrm{mM}, \mathrm{KCl} 1 \mathrm{mM}, \mathrm{CaCl}_{2} 0.41 \mathrm{mM}, \mathrm{Ca}\left(\mathrm{NO}_{3}\right)_{2} \quad 0.33\right.$ $\mathrm{mM}, \mathrm{NaHCO}_{3} 2.4 \mathrm{mM}, \mathrm{MgSO}_{4} 0.83 \mathrm{mM}$, Na pyruvate 250 $\mathrm{mM}$, HEPES $5 \mathrm{mM}, \mathrm{pH} 7.4$, theophylline $0.5 \mathrm{mM}$, Penicillin $10 \mathrm{U} / \mathrm{ml}$, streptomycin $10 \mathrm{U} / \mathrm{ml}$, gentamycin $10 \mathrm{U} / \mathrm{ml}$ ) at $18^{\circ} \mathrm{C}$ for $48-96 \mathrm{hr}$. Incubation medium was changed daily.

\section{Two electrode voltage clamp recording}

After $48-96$ hour incubation period at $18^{\circ} \mathrm{C}$, an oocyte was placed into a Plexiglas recording chamber approximately 300 $\mu \mathrm{L}$ in volume and continuously perfused with $1.8 \mathrm{mM} \mathrm{Ca}^{2+}$ frog Ringer's solution ( $\mathrm{NaCl} 120 \mathrm{mM}, \mathrm{KCl} 2 \mathrm{mM}$, HEPES 5 $\left.\mathrm{mM}, \mathrm{CaCl}_{2} 1.8 \mathrm{mM}, \mathrm{pH} 7.4\right)$ at $3-7 \mathrm{~mL} / \mathrm{min}$. The oocyte was penetrated with two glass electrodes with resistance of $1-$ $3 \mathrm{M} \Omega$ when filled with $3 \mathrm{M} \mathrm{KCl}$ solution. Two electrode voltage clamp recordings at $-50 \mathrm{mV}$ were obtained with an Oocyte Clamp (OC 725C, Warner Instruments, USA).

After 5-HT dose response curves were taken from both wild and mutant receptors expressed functionally, the effects of clinical doses of halothane, 1 and 2 MAC, on 5-HT-mediated currents were compared, in which 5-HT concentration that evokes approximately $20 \%$ of the maximal peak current for each receptor was used $\left(\mathrm{EC}_{20}\right.$ concentration).

Oocytes were preincubated with halothane for $2 \mathrm{~min}$ prior to application of 5-HT for $20-30 \mathrm{~s}$ until the peak current reached. Saturated solutions of halothane were prepared by bubbling of halothane with microbubbler into a sealed bottle of recording solution at a gas flow rate of $200 \mathrm{~mL} / \mathrm{min}$ for more than $30 \mathrm{~min}$. The $100 \% \quad \mathrm{O}_{2}$ was passed through the agent specific calibrated vaporizer. Each experiment was preceded and followed by a control application of 5-HT, both to normalize data and to ensure the reversibility of drug-induced modulation of currents. Cumulative desensitization was excluded by confirming that the control response (within 90\% recovery) was induced. For analysis, the average of these two measurements was used as the control. A 5-30 min recovery period was allowed after each application of agonist (with or without anesthetic). Experiments were repeated in at least four oocytes.

The bath solution exchange time constant was approximately $0.5 \mathrm{~s}$ and orders of magnitude slower than the biochemical interactions between ligand and receptors. The timing of drug 
application and current digitization were controlled by Clampex v 5.2 (Axon Instruments, USA).

5-HT (serotonin), collagenase IA, and almost all the chemicals were purchased from Sigma-Aldrich (USA). Halothane was purchased from Sigma-Aldrich (USA).

\section{Data analysis}

Peak currents induced by the drug applications were measured and concentration- response curves were fit (Sigmaplot v 7.0; SPSS Inc., USA) to the equation $I / I_{\max }=\mathrm{C}^{\mathrm{n}} /\left(\mathrm{C}^{\mathrm{n}}+\mathrm{EC}_{50}{ }^{\mathrm{n}}\right)$ where $\mathrm{I}$ is normalized peak current form serotonin, and $\mathrm{I}_{\max }$ is maximal normalized peak current. $\mathrm{C}$ is the concentration of serotonin, $n$ is Hill coefficient and $\mathrm{EC}_{50}$ is the concentration at which half-maximal peak current is induced.

The inhibitory or potentiating effects of halothane were presented as percentage in comparison with the currents induced by serotonin $\mathrm{EC}_{20}$.

The values represented mean \pm SEM. Statistical analysis was performed using ANOVA with Tukey test for multiple comparison and Mann-Whitney $\mathrm{U}$ test in appropriate. $\mathrm{P}<0.05$ was considered significant.

\section{RESULTS}

Functional characterization of the wild-type and mutant $5-\mathrm{HT}_{3 \mathrm{~A}}$ receptors

E106D, F107Y, R222F, R222V mutant 5-HT $3 \mathrm{~A}$ receptors were functionally expressed but E106Y, F107S, R222P mutant

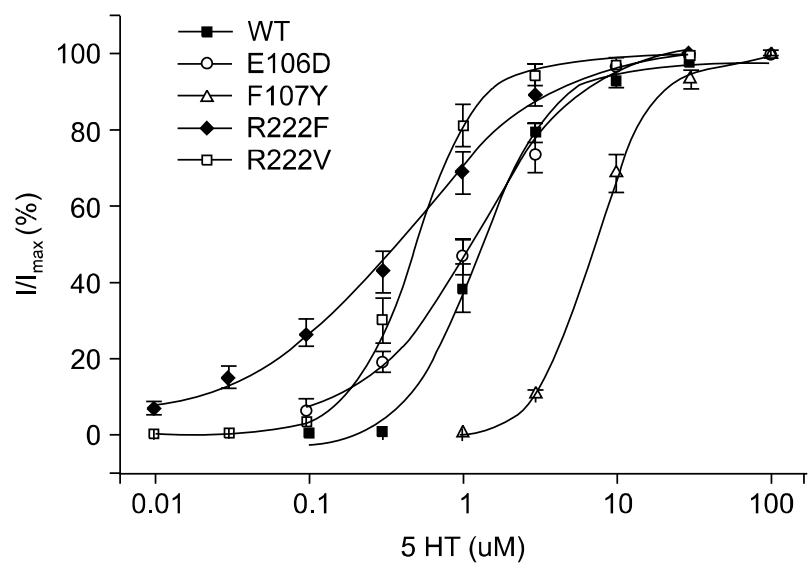

Fig. 1. Concentration response curves for 5-HT in wild type (WT) and mutant $5-\mathrm{HT}_{3 \mathrm{~A}}$ receptors. The $\mathrm{F} 107 \mathrm{Y}$ mutant $5-\mathrm{HT}_{3 \mathrm{~A}}$ receptor decreased the sensitivity to agonists. $I$ and $I_{\max }$ are the current at a given 5-HT concentration and the maximal current, respectively. Each data point represents mean \pm SEM from $5-8$ cells.
5- $\mathrm{HT}_{3 \mathrm{~A}}$ receptor were not functionally expressed even with $1 \mathrm{mM}$ 5-HT. Fig. 1 shows 5-HT concentration-response relationships for currents in wild and mutant $5-\mathrm{HT}_{3 \mathrm{~A}}$ receptors. The 5-HT $\mathrm{EC}_{50}$ values, Hill coefficients and $I_{\max }$ obtained from analyses of these concentration-response curves are listed in Table 1. F107Y mutant receptor displayed decreased sensitivity to 5-HT comparing to the wild receptor, with about 6 - fold rightward shifts observed. Hill coefficients for 5-HT were significantly decreased in E106D and R222F mutant receptors compared with wild-type $5-\mathrm{HT}_{3 \mathrm{~A}}$ receptors.

Modulation of 5-HT $\mathrm{EC}_{20}$-induced currents by halothane according to wild-type and mutant $5-\mathrm{HT}_{3 \mathrm{~A}}$ receptors

Halothane itself did not induce any current in wild and mutant receptors.

Fig. 2 illustrates current tracings, responses to 5-HT with

Table 1. Summary of the Properties of the Wild Type (WT) and Mutant $5-\mathrm{HT}_{3 \mathrm{~A}}$ Receptors Expressed in Xenopus Laevis Oocytes

\begin{tabular}{lccc}
\hline Receptor & 5-HT EC $50(\mu \mathrm{M})$ & Hill coefficient & $I_{\max }(\mu \mathrm{A})$ \\
\hline WT & $1.29 \pm 0.18$ & $2.12 \pm 0.08$ & $3.84 \pm 0.36$ \\
E106D & $1.41 \pm 0.21$ & $1.22 \pm 0.16^{*}$ & $1.05 \pm 0.21$ \\
F107Y & $7.47 \pm 0.85^{*}$ & $2.43 \pm 0.17$ & $7.39 \pm 1.51$ \\
R222F & $0.61 \pm 0.16$ & $0.75 \pm 0.06^{*}$ & $0.38 \pm 0.09$ \\
R222V & $0.50 \pm 0.08$ & $2.24 \pm 0.19$ & $3.51 \pm 0.74$ \\
\hline
\end{tabular}

$\mathrm{EC}_{50}$, Hill coefficient $(n)$, and $I_{\max }$ of the 5-HT concentrationresponse curves for WT and various mutant receptors are listed, expressed as mean \pm SEM of $4-8$ oocytes. These values were obtained by fitting the data to the equation given in the section of "Materials and Methods." The values for mutant receptor were compared with those of the WT receptor, and the statistical significance was calculated using ANOVA with Tukey test for multiple comparisons. *: $\mathrm{P}<0.05$ compared with WT.

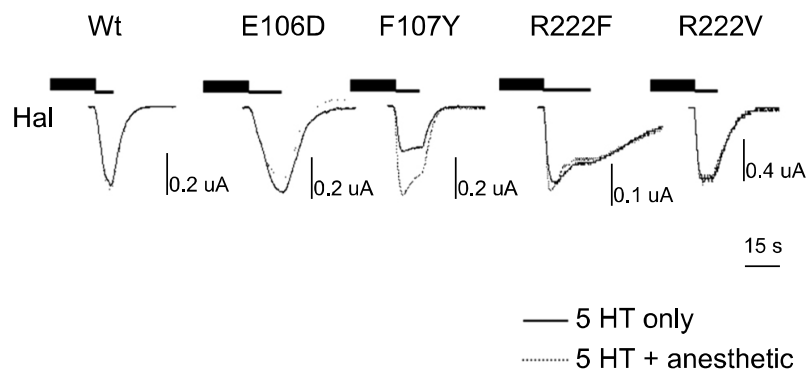

Fig. 2. Representative current tracings, responses to 5-HT with and without halothane in wild-type and mutant $5-\mathrm{HT}_{3 \mathrm{~A}}$ receptors. Oocytes were first preincubated with halothane for $2 \mathrm{~min}$ prior to application of 5-HT. Peak currents were recorded and compared to halothane-free controls. 


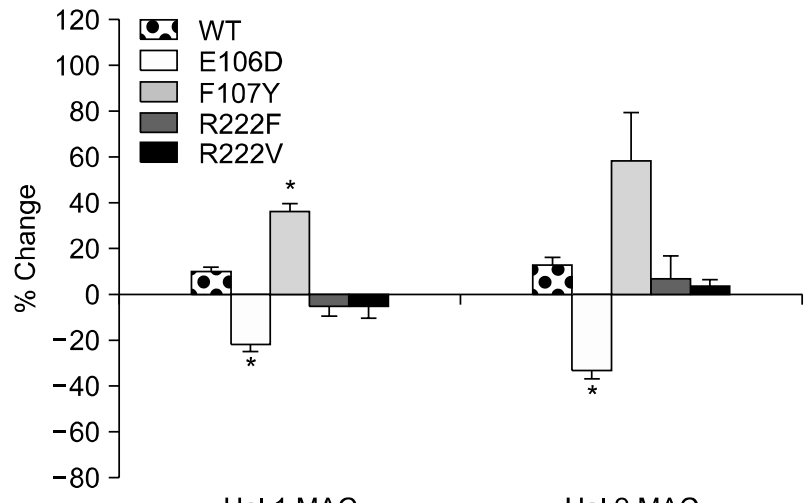

Hal 1 MAC

Hal 2 MAC

Fig. 3. Effects of halothane on 5-HT-induced currents in the wild-type and mutant $5-\mathrm{HT}_{3 \mathrm{~A}}$ receptors. In E106D mutant 5- $\mathrm{HT}_{3 \mathrm{~A}}$ receptor, halothane did not potentiate but inhibited the 5-HT-induced currents. Values are percent change of the control response without halothane. Negative numbers indicate percentage of inhibition. Data from more than 8 oocytes were expressed as mean \pm SEM. *: $\mathrm{P}<0.05$ compared with the value of wild $5-\mathrm{HT}_{3 \mathrm{~A}}$ receptor.

and without halothane in wild-type and mutant $5-\mathrm{HT}_{3 \mathrm{~A}}$ receptors.

Fig. 3 depicts the modulation of 5-HT $\mathrm{EC}_{20}$-induced currents by halothane. The $\mathrm{F} 107 \mathrm{Y}$ mutant $5-\mathrm{HT}_{3 \mathrm{~A}}$ receptor increased positive modulation by halothane. Both R222F and R222V mutant $5-\mathrm{HT}_{3 \mathrm{~A}}$ receptor have little influence on positive modulation by halothane. In marked contrast of these results, E106D mutant 5- $\mathrm{HT}_{3 \mathrm{~A}}$ receptor was negatively modulated by halothane.

\section{DISCUSSION}

In present study, we investigated the effects of single mutation of three amino acid residues (E106, F107, R222), located in the proximal to transmembrane domain 1 of $5-\mathrm{HT}_{3 \mathrm{~A}}$ receptors which are involved in agonist binding and linking the agonist binding to channel gating, on the modulation of the inhalation anesthetics in $5-\mathrm{HT}_{3 \mathrm{~A}}$ receptor.

LGICs seem to be the target receptors of anesthetic action. Most studies of anesthetic mechanism are conducted in nACh receptor or $\mathrm{GABA}_{\mathrm{A}}$ receptors. Along with anesthetic mechanism on LGICs, anesthetics induced side effect such as postoperative nausea and vomiting has focused on the $5-\mathrm{HT}_{3 \mathrm{~A}}$ receptor. LGIC member subunits share significant sequence homology and consists of a large, extracellular N-terminal domain, four transmembrane $\alpha$-helical segments, and an intracellular component. ${ }^{22,24,25)}$ There have been many studies to identify amino acid residues critical for LGIC assembly, agonist affinity, and conductance. ${ }^{5,22,26}$ From these studies, extracellular N-terminal domain is responsible for agonist binding, TM2 domain lines the channel pore and forms the channel gate, and the pre-TM1 region and the TM2-TM3 loop of $5-\mathrm{HT}_{3 \mathrm{~A}}$ receptor are implicated in the coupling process between agonist binding and channel gating. ${ }^{22,25)}$ Also there has been suggested that anesthetic binding site of LGICs exists in transmembrane domain. ${ }^{2427-29)}$ At present, there have been many studies on anesthetic modulation in anesthetic or alcohol binding pocket located in TM2 and/or TM3. ${ }^{15-18)}$ According to these studies, anesthetics and alcohols concentrate in water-filled protein clefts, altering the flexibility of the protein and hence protein function. Miyazawa et al. reported that the L257 residue of the $\alpha$ subunit of the Torpedo nACh receptor (analogous to S267 in the $\alpha 1$ glycine receptor and L270 in the $5-\mathrm{HT}_{3 \mathrm{~A}}$ receptor) faces away from the pore and towards the other three $\alpha$-helical transmembrane domain, presumably forming part of a water-filled cavity in which anesthetics can bind. Mihic et al. ${ }^{19)}$ demonstrated that mutations of two amino acids, serine 267 in TM2 and alanine 288 in TM3 blocked alcohol and anesthetic enhancement of glycine receptor-mediated currents. Mutations of leucine-293 or isoleucine-294 in TM2 of 5- $\mathrm{HT}_{3 \mathrm{~A}}$ receptor alter alcohol modulatory actions. ${ }^{17,18)}$ Also phenylalanine-269 and leucine-270 in TM2 markedly affected alcohol and anesthetic enhancement of $5-\mathrm{HT}_{3 \mathrm{~A}}$ receptor function. ${ }^{15)}$ Mutation of a single amino acid in the extracellular transmembrane segment 2 domain induces resistance to ketamine inhibition in the $\alpha 7$ nicotinic receptor and sensitivity to inhibition in the $5-\mathrm{HT}_{3 \mathrm{~A}}$ receptor. ${ }^{16)}$ For LGICs to be activated, signal transduction travels from the agonist binding to conformational change of the channel. But there have been few studies of the functional role of amino acid residues located in the proximal site to transmembrane domain on anesthetic modulation although these sites are involved in the initial process of the signal transduction pathway. We raised the questions that mutation of single amino acid residues, especially glutamate $106^{21)}$ and phenylalanine $107^{20)}$ thought to be important for agonist binding and arginine $222^{22)}$ for linking of agonist binding to channel gating, might affect the anesthetic modulation in the $5-\mathrm{HT}_{3 \mathrm{~A}}$ receptor.

We constructed 7 individual mutants. Among them E106D, F107Y, R222F, R222V mutant 5- $\mathrm{HT}_{3 \mathrm{~A}}$ receptors were functionally expressed but E106Y, F107S and R222P mutant 5-HT $3 \mathrm{~A}$ receptors were not functionally expressed. The functional char- 
acteristics of expressed wild, E106D, F107Y and R222F mutant $5-\mathrm{HT}_{3 \mathrm{~A}}$ receptors, were comparable with others. ${ }^{20-22,30)}$ F107Y mutant 5- $\mathrm{HT}_{3 \mathrm{~A}}$ receptors displayed decreased sensitivity to 5-HT compared to the wild type 5- $\mathrm{HT}_{3 \mathrm{~A}}$ receptor with 6 fold rightward shift observed $(\mathrm{P}<0.05)$. While the Hill coefficient of $2.12 \pm 0.08$ in wild type receptor indicated positive cooperativity of agonist activation, both E106D and $\mathrm{R} 222 \mathrm{~F}$ mutant $5-\mathrm{HT}_{3 \mathrm{~A}}$ receptors lost a positive cooperativeness (E106D, $1.22 \pm 0.16 ; \mathrm{R} 222 \mathrm{~F}, 0.75 \pm 0.06$ vs. wild type, 2.12 $\pm 0.08, \mathrm{P}<0.05)$. Although functional characteristics of $\mathrm{R} 222 \mathrm{~V}$ mutant $5-\mathrm{HT}_{3}$ receptor were not compared with others, it certainly constructed functional channel to the agonist, 5-HT.

To find the modulation effect of halothane in wild $5-\mathrm{HT}_{3 \mathrm{~A}}$ receptor and various mutant $5-\mathrm{HT}_{3 \mathrm{~A}}$ receptor, we preapplied the saturated halothane for 2 minutes with 1 and 2 MAC, known as positive modulator to $5-\mathrm{HT}_{3 \mathrm{~A}}$ receptor, before applying 5-HT (EC 20 taken from each dose response plot) (Fig. 3). Stevens et al. $^{7)}$ noted that anesthetic modulation in $5-\mathrm{HT}_{3 \mathrm{~A}}$ receptor exhibits a dependence on molecular volume and volatile anesthetics except sevoflurane enhanced the 5-HT-induced currents. In their study, desflurane and halothane enhanced modulation in wild 5- $\mathrm{HT}_{3 \mathrm{~A}}$ receptor similar to this study, although the degrees of enhancing the 5-HT induced currents were greater than those of this study. This difference could be explained from that they used $\mathrm{EC}_{10}$ concentration of 5-HT while this study used $\mathrm{EC}_{20}$ concentration of 5-HT and we just pre-applied the volatile anesthetic before 5-HT applying so that remaining anesthetic concentrations in the measuring bath must be diluted. Halothane showed positive modulation in both wild and $\mathrm{F} 107 \mathrm{Y}$ mutant $5-\mathrm{HT}_{3 \mathrm{~A}}$ receptors and $\mathrm{F} 107 \mathrm{Y}$ mutant $5-\mathrm{HT}_{3}$ receptor showed greater enhancing modulation comparing to wild receptor with 1 MAC of halothane. Meanwhile R222F and $\mathrm{R} 222 \mathrm{~V}$ mutant $5-\mathrm{HT}_{3}$ receptor lost positive modulation with 1 and 2 MAC of halothane. Most interestingly, positive molulation by halothane was converted into negative modulation in E106D mutant 5- $\mathrm{HT}_{3}$ receptor (Fig. 3). The direction of modulation by halothane from mutagenesis of agonist binding sites, glutamate 106 and its adjacent phenylalanine 107 displayed differently. Especially mutation of glutamate into aspartate resulted in shortening of methylene group without altering its polarity. Interestingly, the shortening by methylene group at the side chain of leucine into valine in TM2 domain lost volatile anesthetic's positive modulation. ${ }^{15)}$ But it is not probably rational that simple shortening by methylene group in amino acid residues of agonist binding site or channel pore site determine the anesthetic modulatory direction.

Although this study has limitation for getting kinetic informations from constructed receptors, normalized current tracings of 5-HT induced in presence or absence of halothane displayed identical current shapes in all the constructed receptors except F107Y mutant 5- $\mathrm{HT}_{3 \mathrm{~A}}$ receptor. In F107Y mutant 5- $\mathrm{HT}_{3 \mathrm{~A}}$ receptor, there was rapid desensitization during 5-HT application in presence of halothane. On the contrary, 5-HTinduced gating in $\mathrm{F} 107 \mathrm{Y}$ mutant $5-\mathrm{HT}_{3 \mathrm{~A}}$ receptor expressed in HEK 293 cell, did not display rapid desensitization even with $10 \mathrm{mM}$ concentration of $5-\mathrm{HT}{ }^{20)}$

The anesthetic effects on $5-\mathrm{HT}_{3 \mathrm{~A}}$ receptors may not contribute to the establishment of an anesthetized state but be related to anesthetic induced nausea and vomiting. In vitro study, most volatile anesthetics, such as enflurane, halothane, isoflurane, enhanced 5-HT induced current in wild type 5- $\mathrm{HT}_{3 \mathrm{~A}}$ receptor with varying degree, but sevoflurane or propofol inhibited it. $^{7-11,13)}$ These findings are also noticeable in clinical studies. Philip et al. ${ }^{31)}$ showed that the incidence of postoperative nausea and vomiting after ambulatory anesthesia was lower in the sevoflurane group than in the isoflurane group. Raeder et al. ${ }^{32)}$ reported that the incidence of postoperative nausea and vomiting was decreased following the use of propofol rather than desflurane after laparoscopic cholecystectomy. 5- $\mathrm{HT}_{3 \mathrm{~A}}$ receptors in the area postrema of the brain are believed to be associated with anesthetic associated nausea and vomiting. ${ }^{33)}$

At present, several subtypes of $5-\mathrm{HT}_{3}$ receptor were identified and recombinant $5-\mathrm{HT}_{3 \mathrm{~A}}$ receptor shows most of native $5-\mathrm{HT}_{3}$ receptor properties. Nevertheless, it is not completely clear whether native $5-\mathrm{HT}_{3}$ receptors in different brain area are constituted by homomeric 5- $\mathrm{HT}_{3 \mathrm{~A}}$ pentamer or heteromeric pentamers from combination of $5-\mathrm{HT}_{3 \mathrm{~A}}$ and $5-\mathrm{HT}_{3 \mathrm{~B}}$ or other subtypes. Therefore, mechanisms of anesthetic modulation in $5-\mathrm{HT}_{3}$ receptor seem to be multiple and complex. It was evident from the fact that modulation by volatile anesthetic was decreased in $5-\mathrm{HT} 3_{\mathrm{AB}}$ receptor than in $5-\mathrm{HT}_{3 \mathrm{~A}}$ receptor. Incorporation of $5-\mathrm{HT}_{3 \mathrm{~B}}$ receptor might alter the anesthetic binding site or the allosteric interaction between anesthetic binding and channel opening. ${ }^{34)}$ Furthermore, the additive effects of halothane and ethanol on the $5-\mathrm{HT}_{3}$ receptor suggest the evidence that these compounds have different targeting sites within 5- $\mathrm{HT}_{3}$ receptor. ${ }^{9)}$ But at the molecular level of $5-\mathrm{HT}_{3}$ receptor, anesthetic modulating sites are much more complicated. From this study conducted at the molecular levels of $5-\mathrm{HT}_{3 \mathrm{~A}}$ receptor, anesthetic modulation in $5-\mathrm{HT}_{3 \mathrm{~A}}$ receptor 
were also affected by single mutagenesis of agonist binding sites (glutamate 106 and penylalanine 107) or presumed coupling site (arginine 222) between agonist binding and channel gating as well as of channel pore sites or anesthetic binding pocket in LGICs. ${ }^{10,15,17-19,25,27,35)}$

The underlying mechanism how anesthetics interact with the LGICs is assumed as an allosteric fashion. ${ }^{36}$ As shown in the simplified kinetic scheme involving anesthetic modulation mechanism, allosteric modulation of anesthetics in 5- $\mathrm{HT}_{3 \mathrm{~A}}$ receptors might be achieved by altering agonist binding, the channel gating or linking both or desensitization.

In conclusion, this study has shown that mutation of glutamate 106 into aspartate in $5-\mathrm{HT}_{3 \mathrm{~A}}$ receptor changed the direction of halothane modulation from positive to negative. Mutations of phenylalanine 107 into tyrosine potentiated halothane modulation, while mutation of arginine 222 into phenylalanine or valine lost halothane modulation. These findings, conducted at the molecular level of $5-\mathrm{HT}_{3 \mathrm{~A}}$ receptor, might indicate that anesthetic modulation in $5-\mathrm{HT}_{3 \mathrm{~A}}$ receptor could be affected by the mutation of amino acid residues important for agonist binding and linking agonist to channel gating as well as channel gating.

\section{ACKNOWLEDGEMENT}

This study was supported by a faculty research grant of Yonsei University College of Medicine (6-2004-95).

\section{REFERENCES}

1. Ortells MO, Lunt GG: Evolutionary history of the ligand-gated ion-channel superfamily of receptors. Trends Neurosci 1995; 18: 121-7.

2. Maricq AV, Peterson AS, Brake AJ, Myers RM, Julius D: Primary structure and functional expression of the 5HT3 receptor, a serotonin-gated ion channel. Science 1991; 254: 432-7.

3. Davies PA, Pistis M, Hanna MC, Peters JA, Lambert JJ, Hales TG, et al: The 5-HT3B subunit is a major determinant of serotonin-receptor function. Nature 1999; 397: 359-63.

4. Morales M, Wang SD: Differential composition of 5-hydroxytryptamine3 receptors synthesized in the rat CNS and peripheral nervous system. J Neurosci 2002; 22: 6732-41.

5. Karlin A: Emerging structure of the nicotinic acetylcholine receptors. Nat Rev Neurosci 2002; 3: 102-14.

6. Daniels S, Smith EB: Effect of general anaesthetics on ligand-gated ion channels. Br J Anaesth 1993; 71: 59-64.

7. Stevens RJ, Rusch D, Davies PA, Raines DE: Molecular properties important for inhaled anesthetic action on human 5-HT3A receptors. Anesth Analg 2005; 100: 1696-703.

8. Jenkins A, Franks NP, Lieb WR: Actions of general anaesthetics on 5-HT3 receptors in N1E-115 neuroblastoma cells. Br J Pharmacol 1996; 117: 1507-15.

9. Machu TK, Harris RA: Alcohols and anesthetics enhance the function of 5-hydroxytryptamine3 receptors expressed in Xenopus laevis oocytes. J Pharmacol Exp Ther 1994; 271: 898-905.

10. Miyake A, Mochizuki S, Takemoto Y, Akuzawa S: Molecular cloning of human 5-hydroxytryptamine3 receptor: heterogeneity in distribution and function among species. Mol Pharmacol 1995; 48: 407-16.

11. Suzuki T, Koyama H, Sugimoto M, Uchida I, Mashimo T: The diverse actions of volatile and gaseous anesthetics on human-cloned 5-hydroxytryptamine3 receptors expressed in Xenopus oocytes. Anesthesiology 2002; 96: 699-704.

12. Barann M, Gothert M, Bonisch H, Dybek A, Urban BW: 5-HT3 receptors in outside-out patches of N1E-115 neuroblastoma cells: basic properties and effects of pentobarbital. Neuropharmacology 1997; 36: 655-64.

13. Barann M, Dilger JP, Bonisch H, Gothert M, Dybek A, Urban BW: Inhibition of 5-HT3 receptors by propofol: equilibrium and kinetic measurements. Neuropharmacology 2000; 39: 1064-74.

14. Eisele JL, Bertrand S, Galzi JL, Devillers-Thiery A, Changeux JP, Bertrand D: Chimaeric nicotinic-serotonergic receptor combines distinct ligand binding and channel specificities. Nature 1993; 366: 479-83.

15. Lopreato GF, Banerjee P, Mihic SJ: Amino acids in transmembrane domain two influence anesthetic enhancement of serotonin-3A receptor function. Brain Res Mol Brain Res 2003; 118: 45-51.

16. Ho KK, Flood P: Single amino acid residue in the extracellular portion of transmembrane segment 2 in the nicotinic alpha7 acetylcholine receptor modulates sensitivity to ketamine. Anesthesiology 2004; 100: 657-62.

17. Sessoms-Sikes JS, Hamilton ME, Liu LX, Lovinger DM, Machu TK: A mutation in transmembrane domain II of the 5-hydroxytryptamine $(3 \mathrm{~A})$ receptor stabilizes channel opening and alters alcohol modulatory actions. J Pharmacol Exp Ther 2003; 306: 595-604.

18. Hu XQ, Hayrapetyan V, Gadhiya JJ, Rhubottom HE, Lovinger DM, Machu TK: Mutations of L293 in transmembrane two of the mouse 5-hydroxytryptamine3A receptor alter gating and alcohol modulatory actions. Br J Pharmacol 2006; 148: 88-101.

19. Mihic SJ, Ye Q, Wick MJ, Koltchine VV, Krasowski MD, Finn SE, et al: Sites of alcohol and volatile anaesthetic action on GABA(A) and glycine receptors. Nature 1997; 389: 385-9.

20. Steward LJ, Boess FG, Steele JA, Liu D, Wong N, Steele JA, et al: Importance of phenylalanine 107 in agonist recognition by the 5-hydroxytryptamine3A receptor. Mol Pharmacol 2000; 57: 1249-55.

21. Boess FG, Steward LJ, Steele JA, Liu D, Reid J, Glencorse TA, et al: Analysis of the ligand binding site of the 5-HT3 receptor using site directed mutagenesis: importance of glutamate 106. 
Neuropharmacol 1997; 36: 637-47.

22. Hu Xiang-Q, Zhang L, Stewart RR., Weight FF: Arginine 222 in the pre-transmembrane domain 1 of 5-HT3A receptors links agonist binding to channel gating. J Biol Chem 2003; 278: 46583-9.

23. Zhang L, Oz M, Stewart RR, Peoples RW, Weight FF: Volatile general anaesthetic actions on recombinant nACh alpha 7, 5-HT3 and chimeric nACh alpha 7-5-HT3 receptors expressed in Xenopus oocytes. Br J Pharmacol 1997; 120: 353-5.

24. Miyazawa A, Fujiyoshi Y, Unwin N: Structure and gating mechanism of the acetylcholine receptor pore. Nature 2003; 423: 949-55.

25. Hu XQ, Lovinger DM: Role of aspartate 298 in mouse 5-HT3A receptor gating and modulation by extracellular $\mathrm{Ca} 2+$. J Physiol 2005; 568: 381-96.

26. Tang P, Mandal PK, Xu Y: NMR structures of the second transmembrane domain of the human glycine receptor alpha(1) subunit: model of pore architecture and channel gating. Biophys 2002; 83: $252-62$.

27. Eckenhoff RG, Johansson JS: Molecular interactions between inhaled anesthetics and proteins. Pharmacol Rev 1997; 49: 343-67.

28. Panicker S, Cruz H, Arrabit C, Slesinger PA: Evidence for a centrally located gate in the pore of a serotonin-gated ion channel. J Neurosci 2002; 22: 1629-39.

29. Reeves DC, Lummis SC: The molecular basis of the structure and function of the 5-HT3 receptor: a model ligand-gated ion channel. Mol Membr Biol 2002; 19: 11-26.
30. Zhang L, Hosoi M, Fukuzawa M, Sun H, Rawlings RR, Weight FF: Distinct molecular basis for differential sensitivity of the serotonin type $3 \mathrm{~A}$ receptor to ethanol in the absence and presence of agonist. J Biol Chem 2002; 277: 46256-64.

31. Philip BK, Kallar SK, Bogetz MS, Scheller MS, Wetchler BV: A multicenter comparison of maintenance and recovery with sevoflurane or isoflurane for adult ambulatory anesthesia. The Sevoflurane Multicenter Ambulatory Group. Anesth Analg 1996; 83: 314-9.

32. Raeder JC, Mjåland $\mathrm{O}, \operatorname{Aasbø~V,~Grøgaard~B,~Buanes~T:~}$ Desflurane versus propofol maintenance for outpatient laparoscopic cholecystectomy. Acta Anaesthesiol Scand 1998; 42: 106-10.

33. Aapro MS: 5-HT3 receptor antagonists. An overview of their present status and future potential in cancer therapy-induced emesis. Drugs 1991; 42: 551-68.

34. Stevens R, Rusch D, Solt K, Raines DE, Davies PA: Modulation of human 5-hydroxytryptamine type $3 \mathrm{AB}$ receptors by volatile anesthetics and n-alcohols. J Pharmacol Exp Ther 2005; 314: 338-45.

35. Jenkins A, Greenblatt EP, Faulkner HJ, Bertaccini E, Light A, Lin A, et al: Evidence for a common binding cavity for three general anesthetics within the GABAA receptor. J Neurosci 2001; 21: RC136.

36. Dilger JP: The effects of general anaesthetics on ligand-gated ion channels. Br J Anaesth 2002; 89: 41-51. 